\title{
Stocking densities and feeding strategies in shrimp and tilapia polyculture in tanks
}

\author{
Bruno Rodrigo Simão(1), Luis Otavio Brito(2), Alex Sandro Campos Maia( ${ }^{(3)}$, Laizy Cabral Miranda(4), \\ and Celicina Maria da Silveira Borges Azevedo(4)
}

\begin{abstract}
(1)Universidade Federal Rural do Semi-Árido (Ufersa), Departamento de Ciências Ambientais, BR-110, Km 47, Presidente Costa e Silva, CEP 59625-900 Mossoró, RN, Brazil. E-mail: bruno@ufersa.edu.br (2)Instituto Agronômico de Pernambuco, Avenida General San Martin, no 1.371, Bongi, CEP 50761-000 Recife, PE, Brazil. E-mail: luis.otavio@ipa.br (3)Universidade Estadual Paulista, Faculdade de Ciências Agrárias, Departamento de Zootecnia, CEP 14884-900 Jaboticabal, SP, Brazil. E-mail: alex.maia@fcav.unesp.br (4)Ufersa, Departamento de Ciências Animais. E-mail: laizymiranda@hotmail.com, celicina@gmail.com
\end{abstract}

\begin{abstract}
The objective of this work was to evaluate the performance of Pacific marine shrimp (Litopenaeus vannamei) and tilapia (Oreochromis niloticus), in a polyculture in tanks subjected to different stocking densities and feeding strategies, in comparison with monoculture. Two experiments were performed, at the same time, in a completely randomized design with three treatments and four replicates each. Treatments for experiment I were: monoculture with 10 shrimp per $\mathrm{m}^{2}$ (10S:0T); polyculture with 10 shrimp and 0.5 tilapia per $\mathrm{m}^{2}$ (10S:0.5T); and polyculture with 10 shrimp and 1 tilapia per $\mathrm{m}^{2}$ (10S:1T). Shrimp was the main crop, and feed was provided based on shrimp biomass. Treatments for experiment II were: monoculture with 2 tilapia per $\mathrm{m}^{2}$ (2T:0S); polyculture with 2 tilapia and 2.5 shrimp per $\mathrm{m}^{2}$ (2T:2.5S); and polyculture with 2 tilapia and 5 shrimp per $\mathrm{m}^{2}$ (2T:5S). Tilapia was the main crop, and feed was provided based on fish requirements. In the experiment I, tilapia introduction to shrimp culture resulted in lower shrimp growth and poor feed conversion rate. In experiment II, shrimp introduction to tilapia culture did not interfere with fish performance. Polyculture is more efficient with the combination of 2 tilapia and 2.5 or 5 shrimp per $\mathrm{m}^{2}$ and feed based on fish requirements.

Index terms: Litopenaeus vannamei, Oreochromis niloticus, aquaculture efficiency, feeding strategie.

\section{Densidades de estocagem e estratégias de alimentação em policultivo de camarão e tilápia em tanques}

Resumo - O objetivo deste trabalho foi avaliar o desempenho de camarão marinho (Litopenaeus vannamei) e tilápia (Oreochromis niloticus) em policultivo, em tanques de cimento, submetido a diferentes densidades de estocagem e estratégias de alimentação, em comparação ao monocultivo. Dois experimentos foram conduzidos, ao mesmo tempo, em delineamento inteiramente casualizado, com três tratamentos e quatro repetições cada um. Os tratamentos do experimento I foram: monocultivo com 10 camarões por $\mathrm{m}^{2}$ (10S:0T); policultivo com 10 camarões e 0,5 tilápia por $\mathrm{m}^{2}$ (10S:0.5T); e policultivo com 10 camarões e 1 tilápia por $\mathrm{m}^{2}(10 \mathrm{~S}: 1 \mathrm{~T})$. O camarão foi a principal cultura, e a alimentação fornecida foi baseada na biomassa de camarão. Os tratamentos do experimento II foram: monocultivo com 2 tilápias por $\mathrm{m}^{2}$ (2T:0S); policultivo com 2 tilápias e 2,5 camarões por $\mathrm{m}^{2}(2 \mathrm{~T}: 2.5 \mathrm{~S})$; e policultivo com 2 tilápias e 5 camarões por $\mathrm{m}^{2}$ (2T:5S). A tilápia foi a principal cultura, e a alimentação fornecida foi baseada na necessidade dos peixes. No experimento I, a introdução da tilápia no cultivo de camarão resultou em baixo crescimento do camarão e baixa taxa de conversão alimentar. No experimento II, a introdução de camarão no cultivo de tilápia não interferiu no desempenho dos peixes. O policultivo é mais eficiente com a combinação de 2 tilápias e 2,5 ou 5 camarões por $\mathrm{m}^{2} \mathrm{e}$ alimentação baseada na necessidade dos peixes.

Termos para indexação: Litopenaeus vannamei, Oreochromis niloticus, eficiência aquícola, estratégia de alimentação.

\section{Introduction}

From 1997 to 2003, shrimp production in Brazil has expanded from 3,600 to more than $90,000 \mathrm{Mg} \mathrm{ha}^{-1}$ per year, representing an increase of more than $2,400 \%$. In just six years, productivity increased from 1,050 to $6,084 \mathrm{~kg} \mathrm{ha}^{-1}$ per year in 2003 , an increase of more than $490 \%$. However, in 2004, production and productivity decreased $15.8 \%$ and $24.8 \%$, respectively, in comparison with 2003. By 2005, production went down to $65,000 \mathrm{Mg} \mathrm{ha}^{-1}$ per year, a reduction of more than $14 \%$ compared to 2004. From 2005 to 2009, 
annual shrimp production remained between 63,000 and $70,000 \mathrm{Mg} \mathrm{ha}^{-1}$, increasing to $80,000 \mathrm{Mg} \mathrm{ha}^{-1}$ in 2010 (Nunes et al., 2011).

This significant drop of shrimp farm production in Brazil, in 2005, was due to many different factors, such as shrimp diseases, difficulty in obtaining new environmental licenses and new funding, flooding and disruption of ponds, which occurred primarily in Rio Grande do Norte and Ceará, and to problems resulting from the antidumping action carried out by the Southern Shrimp Alliance (SSA) in the United States. The combination of these factors forced many farmers into bankruptcy, and those who remained in the market reduced shrimp stocking density and sought alternatives to overcome these difficulties.

Besides reducing stocking density, many farmers in Northeast Brazil adopted a tilapia-shrimp polyculture system as an alternative to overcome the problems, reduce costs and increase shrimp farm sustainability. In Northeast Brazil, farmers consider tilapia the main crop, and feed supplied for fish and shrimp is introduced at low densities. In Thailand, however, shrimp is considered the main crop, and polyculture is performed in different ways: simultaneously, or by crop rotation systems. In both systems, tilapia were directly stocked in shrimp ponds or stocked in cages placed in shrimp ponds (Yi \& Fitzsimmons, 2004).

A production strategy that combines two or more complementary species can increase productivity by an adjustment in the food chain structure which is rearranged to make a better use of natural food, reducing the demand for artificial food (Milstein, 1997; Lutz, 2003). A proper combination of ecologically different species at adequate densities will make the system more efficient because grazing pressure is distributed among different feeding niches and levels, and wastes from one species can be utilized by another (Milstein, 1997).

Tilapia-shrimp or tilapia-prawn polyculture adoption has been expanded among producers in many countries, and some studies have been conducted to test the efficiency of these systems (Candido et al., 2005; Tendencia et al., 2006, 2011; Muangkeow et al., 2007; Uddin et al., 2007, 2009; El-Sherif \& Ali Mervat, 2009; Souza et al., 2009; Martínez-Porchas et al., 2010; Yuan et al., 2010; Shahin et al., 2011; Bessa Junior et al., 2012).
The objective of this work was to evaluate the performance of Pacific marine shrimp, Litopenaeus vannamei (Boone, 1931), and Nile tilapia, Oreochromis niloticus (Linnaeus, 1758), in a polyculture in tanks, subjected to different stocking densities and feed strategies, in comparison with monoculture.

\section{Materials and Methods}

Two experiments were conducted simultaneously at the Universidade Federal Rural do Semi-Árido (Ufersa) in Mossoró, RN, Brazil ( $\left.5^{\circ} 11^{\prime} \mathrm{S}, 37^{\circ} 20^{\prime} \mathrm{W}\right)$ over a period of 95 days, from March to June 2006. Experiments were performed at the same time to eliminate any possible interference related to climatological conditions. A complete randomized design was used with three treatments per experiment, and four replicates each, with a total of 12 experimental units per experiment. In experiment I, all three treatments had 10 shrimp per $\mathrm{m}^{2}$, combined with three tilapia densities at $0,0.5$ and 1 tilapia per $\mathrm{m}^{2}$. In experiment II, all three treatments had 2 tilapias per $\mathrm{m}^{2}$, combined with three shrimp densities $-0,2.5$ and 5.0 shrimp per $\mathrm{m}^{2}$.

In experiment I, shrimp was the main crop, and a commercial shrimp feed with $30 \%$ crude protein (pellet diameter between 2 and $2.5 \mathrm{~mm}$ ) was offered in trays, based on shrimp biomass and according to a feed Table (Clifford, 1992). The initial daily feeding rate of $5.5 \%$ of body weight decreased to $2.5 \%$ final rate as shrimp increased weight.

In experiment II, tilapia was the main crop, and a floating commercial extruded tilapia feed with $32 \%$ crude protein ( $4 \mathrm{~mm}$ pellet) was supplied based on fish biomass and according to a feed Table (Kubitza, 2000 ), with the feeding rate changing from $10 \%$ to $2 \%$ of tilapia body weight.

Ten-day-old postlarvae of L. vannamei from a commercial hatchery (Compescal Larvicultura Ltda., Aracati, CE), and Nile tilapia fingerlings from a government fish hatchery (Departamento Nacional de Obras Contra as Secas (DNOCS, Caicó, RN) were acclimated at $0.4 \%$ salinity and kept in separate tanks for 30 days before being stocked in experimental tanks.

Average shrimp weights, in the beginning of experiment I, were: $0.33 \pm 0.06 \mathrm{~g}$ (10S:0T); $0.36 \pm 0.05 \mathrm{~g}$ (10S:0.5T); $0.35 \pm 0.04 \mathrm{~g}(10 \mathrm{~S}: 1 \mathrm{~T})$. At the beginning of experiment II, average shrimp weights were: $0.36 \pm 0.07$ (2T:2.5S); and $0.27 \pm 0.03 \mathrm{~g}$ (2T:5S). Average fish weights at the beginning of experiment I

Pesq. agropec. bras., Brasília, v.48, n.8, p.1088-1095, ago. 2013 DOI: 10.1590/S0100-204X2013000800039 
were: $7.61 \pm 0.95$ (10S:0.5T); and $8.53 \pm 0.69$ (10S:1T). At the beginning of experiment II, average fish weights were: $8.54 \pm 0.37$ (2T:0C); $7.98 \pm 0.58$ (2T:2.5S); and $7.92 \pm 0.35$ (2T:5S).

The experimental units were $15 \mathrm{~m}^{2}$ cement tanks, $1.2 \mathrm{~m}$ deep, with $5 \mathrm{~cm}$ soil layer substrate. Half of the tank capacity was filled with water from a previous cultivation, and the other half with well water. Water salinity was around $0.4 \%$, and there was no water exchange during the experiments. The tanks were supplied with well water only to replace the evaporated volume, and no aeration was provided during the experimental period.

One week before animals were stocked, the experimental tanks were fertilized, according to Kubitza (2000), with urea and superphosphate at a ratio of $20 \mathrm{~kg}$ of $\mathrm{N}$ and $10 \mathrm{~kg}$ of $\mathrm{P}$ per hectare. A sodium nitrate fertilizer was also used to stimulate natural food production. Between the $2^{\text {nd }}$ and $4^{\text {th }}$ weeks, $30 \mathrm{~kg} \mathrm{ha}^{-1}$ were applied, with $20 \mathrm{~kg} \mathrm{ha}^{-1}$ applied between the $5^{\text {th }}$ and $7^{\text {th }}$ weeks and a further $10 \mathrm{~kg} \mathrm{ha}^{-1}$ between the $8^{\text {th }}$ and $10^{\text {th }}$ weeks. The tanks were randomly assigned to treatments in each experiment.

Water temperature and dissolved oxygen concentration were recorded daily, except for sundays, using an YSI model 550A oxygen meter (YSI, Yellow Springs, OH, USA). Water data were collected from the tank bottom at $7 \mathrm{~h}$ and $17 \mathrm{~h}$. Water salinity and $\mathrm{pH}$ were measured at the tank surface once a week at $17 \mathrm{~h}$, using a portable refractometer, model 211 Briobrix (Equipar Ltda., Curitiba, PR, Brazil), and a digital pH-1700 pH meter (Instrutherm Instrumentos de Medição Ltda., São Paulo, SP, Brazil) respectively.
Estimated shrimp and tilapia biomass was based on monthly growth samples of $10 \%$ population of each tank, using a $15 \mathrm{~mm}$ mesh net. Shrimp and tilapia were separated and weighed in a bunch using an electronic scale (Marte Balanças e Aparelhos de Precisão Ltda., São Paulo, SP Brazil) with 0.01 g precision. At harvest, all shrimp and fish were individually weighed and counted. Based on these evaluations, total weight gain, feed conversion ratio (FCR), survival rate and yield were calculated by: total weight gain $(\mathrm{g})=$ final total weight - initial total weight; feed conversion ratio $(\mathrm{FCR})=$ consumed feed $($ dry weight $) /$ weight gain; survival rate $(\%)=($ number at harvest $\mathrm{x} 100) /$ number at stocking; yield $\left(\mathrm{g} \mathrm{m}^{-2}\right)=$ final biomass per square mefer.

Before proceeding to the variance analysis, data were tested for normality by Shapiro-Wilk test, and homogeneity of variance by Lavene test using the univariate SAS (Statistical Analysis System, version 6.10) procedure. Data were analyzed by the method of least squares as described by Littell et al. (1991) and, when significant differences among treatments $(p<0.05)$ were observed, a Tukey's test was applied to compare means. The PROC GLM and PROC REG procedures of SAS (Statistical Analysis System, version 6.10) were used to perform ANOVA and regression analysis, respectively.

\section{Results and Discussion}

In experiment I, as tilapia density increased, shrimp mean final weight, survival and yield decreased, showing a negative linear effect (Table 1). For

Table 1. Mean and standard error mean $(\mu \pm$ SEM) for initial weight (IW), mean final weight (MFW), survival rate (S), mean yield (Y), and feed conversion ratio (FCR) for shrimp (Litopenaeus vannamei) and tilapia (Oreochromis niloticus), in monoculture or polyculture, in experiment $\mathrm{I}^{(1)}$.

\begin{tabular}{|c|c|c|c|c|c|c|}
\hline \multirow[t]{2}{*}{ Productive variable } & \multirow[t]{2}{*}{ Species } & \multicolumn{3}{|c|}{ Treatment $^{(2)}$} & \multirow[t]{2}{*}{$\mathrm{R}^{2}$} & \multirow[t]{2}{*}{ Regression equation } \\
\hline & & 10C:0T & $10 \mathrm{C}: 0.5 \mathrm{~T}$ & $10 \mathrm{C}: 1 \mathrm{~T}$ & & \\
\hline \multirow{2}{*}{ IW (g) } & Shrimp & $0.33 \pm 0.03 \mathrm{a}$ & $0.36 \pm 0.03 a$ & $0.35 \pm 0.02 \mathrm{a}$ & - & - \\
\hline & Tilapia & - & $7.61 \pm 0.48 \mathrm{a}$ & $8.53 \pm 0.34 a$ & - & - \\
\hline \multirow{2}{*}{ MFW (g) } & Shrimp & $7.87 \pm 4.14 \mathrm{a}$ & $4.98 \pm 4.14 \mathrm{a}$ & $3.17 \pm 4.14 \mathrm{a}$ & 0.9157 & $y=-2.41 x+10.12$ \\
\hline & Tilapia & - & $275.85 \pm 4.14 \mathrm{a}$ & $191.57 \pm 4.14 b$ & 0.9905 & $y=-180.06 x^{2}+816.03 x-635.97$ \\
\hline \multirow{2}{*}{$\mathrm{S}(\%)$} & Shrimp & $78.26 \pm 1.77 \mathrm{a}$ & $74.66 \pm 4.38 \mathrm{a}$ & $64.09 \pm 1.63 b$ & 0.7182 & $y=-6.55 x+85.79$ \\
\hline & Tilapia & - & $87.33 \pm 0.33 \mathrm{a}$ & $88.91 \pm 2.50 \mathrm{a}$ & 0.9982 & $y=-42.505 x^{2}+215.97 x-173.09$ \\
\hline \multirow{2}{*}{$\mathrm{Y}\left(\mathrm{g} \mathrm{m}^{-2}\right)$} & Shrimp & $61.36 \pm 3.17 \mathrm{a}$ & $36.28 \pm 3.17 b$ & $18.37 \pm 3.17 \mathrm{c}$ & 0.8615 & $y=-237.88 x+84.712$ \\
\hline & Tilapia & - & $128.77 \pm 3.17 \mathrm{~b}$ & $183.17 \pm 3.17 \mathrm{a}$ & 0.9961 & $y=-371.83 x^{2}+2403.17 x-2031.3$ \\
\hline FCR & Shrimp & $1.82 \pm 0.10 \mathrm{a}$ & $2.36 \pm 0.10 \mathrm{~b}$ & $2.94 \pm 0.11 \mathrm{c}$ & 0.8633 & $y=0.57 x+1.24$ \\
\hline
\end{tabular}

${ }^{(1)}$ Means on the same line, followed by equal letters, do not differ, by Tukey's test, at 5\% probability. ${ }^{(2)}(10 \mathrm{~S}: 0 \mathrm{~T})$, shrimp monoculture with 10 shrimp per $\mathrm{m}^{2}$; (10S:0.5T), 10 shrimp per $\mathrm{m}^{2}$ and 0.5 tilapia per $\mathrm{m}^{2}$; (10S:1T), 10 shrimp per $\mathrm{m}^{2}$ and 1 tilapia per $\mathrm{m}^{2}$. 
tilapia, mean final weight, survival and yield, in the polyculture system resulted in a quadratic effect. The maximum predicted values for tilapia mean final weight $(288.69 \mathrm{~g})$ is at a density of 0.57 tilapia per $\mathrm{m}^{2}$; for survival (98.85\%), density is at 0.63 tilapia per $\mathrm{m}^{2}$; and, for yield $\left(185.16 \mathrm{~g} \mathrm{~m}^{-2}\right)$, at a density of 1.08 tilapia per square meter. Feed conversion ratio decreased, showing an increasing linear effect as tilapia density increased.

In experiment II, adding shrimp to tilapia culture at low density ( 2.5 shrimp per $\left.\mathrm{m}^{2}\right)$ did not significantly affect the final mean weight, survival or yield for neither species. However, when five shrimp per square meter (2T: $5 \mathrm{~S}$ ) were added, shrimp survival and tilapia yield significantly decreased (Table 2).

The increase of shrimp density resulted in a quadratic effect on survival and yield in both species. The maximum predicted survival value for shrimp $(88.90 \%)$ is reached at a shrimp density of 2.7 shrimp per $\mathrm{m}^{2}$ and, for tilapia (97.39\%), at a shrimp density of 2.5 shrimp per $\mathrm{m}^{2}$. For tilapia yield $\left(500.78 \mathrm{~g} \mathrm{~m}^{-2}\right)$ and shrimp yield $\left(30.56 \mathrm{~g} \mathrm{~m}^{-2}\right)$, the maximum predicted value is reached at shrimp densities of 2.4 and 5.0 per $\mathrm{m}^{2}$ respectively. Feed conversion ratio also showed a quadratic effect, tending to increase from a shrimp density of 2.7 per $\mathrm{m}^{2}$. However, the effect was not statistically significant.

Average water temperature was high (above $30^{\circ} \mathrm{C}$ ). A slight reduction in dissolved oxygen was observed in the polyculture treatments, but levels remained high throughout the experiment. Mean values are shown in Table 3 for both experiments.
Afternoon mean temperature was higher in both experiments, but it did not vary among treatments. Because the thermal comfort range for tilapia is between 27 and $32^{\circ} \mathrm{C}$ (Kubitza 2000), tilapia performance was probably not affected by temperature. Ideal temperatures for shrimp can vary according to mean size; small or medium shrimp growth faster in water temperatures between 26 and $32^{\circ} \mathrm{C}$ (Van Wyk \& Scarpa, 1999). Therefore, in the present work, afternoon temperature was slightly higher than the ideal. However, it is unlikely that this variation above the comfort temperature caused a significant impact on shrimp performance, considering that the oscillation was temporary and common to all treatments. Morning dissolved oxygen was lower in polyculture treatments for experiment I, but remained above $5 \mathrm{mg} \mathrm{L}^{-1}$ in both experiments which, according to Van Wyk \& Scarpa (1999), is better for shrimp growth. Average $\mathrm{pH}$ was above 7 and within the range of 7.0 to 9.0, as recommended for optimal fish and shrimp performance (Van Wyk \& Scarpa, 1999). Mean water salinity was lower than the initial well water $(0.4 \%)$, due to the rains that occurred during the experimental period, but it was still within the necessary range for shrimp survival and growth (above a minimum salinity of $0.05 \%$ ) (Van Wyk \& Scarpa, 1999).

In experiment $\mathrm{I}$, in which tilapia was introduced in a shrimp culture and feed was provided for shrimp, the performance of both species in polyculture decreased, showing lower mean final weight, yield and survival, which resulted in a poor FCR, when compared with monoculture. As tilapia are more agile, they could

Table 2. Mean and standard error mean ( $\mu \pm \mathrm{SEM})$ for initial weight (IW), mean final weight (MFW), survival rate (S), mean yield (Y), and feed conversion ratio (FCR), for shrimp (Litopenaeus vannamei) and tilapia (Oreochromis niloticus), in monoculture or in polyculture, in experiment $\mathrm{II}^{(1)}$.

\begin{tabular}{|c|c|c|c|c|c|c|}
\hline \multirow{2}{*}{$\begin{array}{l}\text { Productive } \\
\text { variable }\end{array}$} & \multirow[t]{2}{*}{ Species } & \multicolumn{3}{|c|}{ Treatment $^{(2)}$} & \multirow[t]{2}{*}{$\mathrm{R}^{2}$} & \multirow[t]{2}{*}{ Regression equation } \\
\hline & & 2T:0S & $2 \mathrm{~T}: 2.5 \mathrm{~S}$ & $2 \mathrm{~T}: 5 \mathrm{~S}$ & & \\
\hline \multirow[t]{2}{*}{$\mathrm{IW}(\mathrm{g})$} & Shrimp & - & $0.36 \pm 0.04 \mathrm{a}$ & $0.27 \pm 0.01 \mathrm{a}$ & - & - \\
\hline & Tilapia & $8.54 \pm 0.19 \mathrm{a}$ & $7.98 \pm 0.29 \mathrm{a}$ & $7.92 \pm 0.17 \mathrm{a}$ & - & - \\
\hline \multirow[t]{2}{*}{ MFW (g) } & Shrimp & - & $10.64 \pm 5.76 \mathrm{a}$ & $9.33 \pm 5.76 \mathrm{a}$ & - & - \\
\hline & Tilapia & $248.82 \pm 5.76 \mathrm{a}$ & $260.62 \pm 5.76 \mathrm{a}$ & $258.05 \pm 5.76 \mathrm{a}$ & - & - \\
\hline \multirow[t]{2}{*}{ S (\%) } & Shrimp & - & $82.97 \pm 1.43 \mathrm{a}$ & $70.08 \pm 1.43 b$ & 0.9967 & $y=-47.52 x^{2}+510.20 x-1280.54$ \\
\hline & Tilapia & $94.65 \pm 1.43 \mathrm{a}$ & $98.75 \pm 1.43 \mathrm{a}$ & $93.33 \pm 1.43 \mathrm{a}$ & 0.5459 & $y=-4.76 x^{2}+46.97 x-17.01$ \\
\hline \multirow[t]{2}{*}{$\mathrm{Y}\left(\mathrm{g} \mathrm{m}^{-2}\right)$} & Shrimp & - & $23.27 \pm 53.42 \mathrm{a}$ & $30.55 \pm 53.42 \mathrm{a}$ & 0.9394 & $y=-79.92 x^{2}+951.93 x-2529.02$ \\
\hline & Tilapia & $483.51 \pm 5.34 \mathrm{a}$ & $499.16 \pm 5.34 \mathrm{a}$ & $455.79 \pm 5.34 \mathrm{~b}$ & 0.6592 & $\mathrm{y}=-295.09 \mathrm{x}^{2}+2812.3 \mathrm{x}-1692.7$ \\
\hline FCR & Tilapia & $1.59 \pm 0.04 \mathrm{a}$ & $1.48 \pm 0.04 \mathrm{a}$ & $1.50 \pm 0.04 \mathrm{a}$ & 0.5802 & $\mathrm{y}=0.10 \mathrm{x}^{2}-1.08 \mathrm{x}+4.25$ \\
\hline
\end{tabular}

${ }^{(1)}$ Means on the same line, followed by equal letters, do not differ, by Tukey's test, at $5 \%$ probability. (2)(2T:0S), tilapia monoculture with 2 tilapia per $\mathrm{m}^{2}$; (2T:2.5S), 2 tilapia per $\mathrm{m}^{2}$ and 2.5 shrimp per $\mathrm{m}^{2}$; (2T:5S), 2 tilapia per $\mathrm{m}^{2}$ and 5 shrimp per $\mathrm{m}^{2}$. 
monopolize feed, leaving less feed than required by shrimp (Yi et al., 2004), which was probably the reason for poor performance of both species. Because feed was provided based on shrimp biomass, the amount of feed was not enough for both species.

Therefore, it can be questioned why producers in Thailand adopt such a system with shrimp as the main crop. In an experiment conducted with tilapia (O. niloticus) and shrimp (Penaeus monodon) in Thailand, Yi et al. (2004) determined that shrimp final mean weight was not statistically different in monoculture, in comparison with a low density and a higher density polyculture. It is important to account for what was considered as low and high density in that study. They used 30 shrimp per $\mathrm{m}^{2}$ in all the cultures, with 0.25 tilapia per $\mathrm{m}^{2}$ at low density, and 0.5 tilapia per $\mathrm{m}^{2}$ at high density. The shrimp:tilapia ratio was 120:1 in the low density treatment and 60:1 in the high density treatment, while in our study the shrimp:tilapia ratio was 20:1 (low density), and 10:1 (high density). In the study by Yi et al. (2004), with a high ratio of shrimp to tilapia, it is possible that tilapia mostly fed on natural food and did not interfere with shrimp performance, as observed in our experiment.

In fact, authors emphasize that tilapias should be kept in cages, even with additional cost, because if they are left outside cages, competition for food reduces shrimp growth, resulting in lower shrimp performance (Yi et al., 2004). It is therefore understandable that, in our study, with a low shrimp:tilapia ratio and tilapias kept free in the water column, competition for pellet feed was very intense, reducing shrimp and tilapia performance.

Muangkeow et al. (2007), in an experiment with a mixed shrimp-tilapia polyculture system, also observed that when the shrimp:tilapia ratio was low (13:1 and
20:1), the presence of tilapia affects shrimp weight because fish and shrimp compete for natural food. In this same study, they observed that shrimp grew, when the shrimp:tilapia ratio was higher (40:1 and 100:1) in monoculture. In an experiment with tilapia-shrimp (3:1) with 20,000, 30,000 and 40,000 animals per hectare, in a polyculture system, Uddin et al. (2007) did not observe effects on shrimp final weight or specific growth rate (SGR); however, the final tilapia weight decreased.

In contrast with experiment I, productivity was higher for polyculture in experiment II, in which tilapia was considered the main crop. Shrimp introduction at 2.5 per $\mathrm{m}^{2}$ density did not interfere with tilapia mean final weight in comparison to monoculture. Shrimp final weight reached $10.47 \mathrm{~g}$ in the $(2 \mathrm{~T}: 2.5 \mathrm{~S})$ treatment, in 95 days of culture, without any feed being provided for shrimp.

Bessa Junior et al. (2012) tested tilapia density (O. niloticus) at 2 tilapia per $\mathrm{m}^{2}$ and shrimp densities $\left(3,6,9,12\right.$ shrimp per $\left.\mathrm{m}^{2}\right)$ in a polyculture, and Yuan et al. (2010) tested tilapia (Oreochromis sp.) at 0.4, 0.8 and 1.2 tilapia per $\mathrm{m}^{2}$ and shrimp at 60 shrimp per $\mathrm{m}^{2}$, also in a polyculture, and they observed a decreased shrimp final weight as stocking density increased; however, these treatments did not significantly affect tilapia biomass, and authors concluded that polyculture with shrimp did not affect Nile tilapia yield. However, El-Sherif \& Ali Mervat (2009) tested one tilapia (12 tilapia per $\left.\mathrm{m}^{2}\right)$ and four shrimp densities $(50,100$, 150 and 200 shrimp per $\mathrm{m}^{2}$ ), in a polyculture, and observed a decreased shrimp and tilapia final weights as stocking density increased.

Candido et al. (2005), in a polyculture of tilapia (O. niloticus) with shrimp (L. vannamei), harvested shrimp with weights of $13.33,14.23$ and $14.01 \mathrm{~g}$, in

Table 3. Mean and standard error mean $\left(\mu \pm\right.$ SEM) for water quality parameters in experiments I and $\mathrm{II}^{(1)}$.

\begin{tabular}{|c|c|c|c|c|c|c|c|c|}
\hline \multirow[t]{2}{*}{ Parameter } & \multirow{2}{*}{$\begin{array}{l}\text { Time } \\
\text { (h) }\end{array}$} & \multirow[t]{2}{*}{$\mathrm{N}$} & \multicolumn{3}{|c|}{ Experiment $\mathrm{I}^{(2)}$} & \multicolumn{3}{|c|}{ Experiment II ${ }^{(2)}$} \\
\hline & & & 10S:0T & $10 \mathrm{~S}: 0.5 \mathrm{~T}$ & 10S:1T & 2T:0S & $2 \mathrm{~T}: 2.5 \mathrm{~S}$ & $2 \mathrm{~T}: 5 \mathrm{~S}$ \\
\hline \multirow{2}{*}{ Temperature $\left({ }^{\circ} \mathrm{C}\right)$} & 07:00 & 328 & $30.22 \pm 0.03 \mathrm{aA}$ & $30.18 \pm 0.03 \mathrm{aA}$ & $30.26 \pm 0.03 \mathrm{aA}$ & $30.32 \pm 0.032 \mathrm{aA}$ & $30.29 \pm 0.032 \mathrm{aA}$ & $30.16 \pm 0.032 \mathrm{bA}$ \\
\hline & $17: 00$ & 328 & $32.01 \pm 0.03 \mathrm{aB}$ & $32.01 \pm 0.03 \mathrm{aB}$ & $32.09 \pm 0.03 \mathrm{aB}$ & $32.20 \pm 0.034 \mathrm{aB}$ & $32.10 \pm 0.034 \mathrm{aB}$ & $31.94 \pm 0.034 \mathrm{bB}$ \\
\hline \multirow{2}{*}{$\begin{array}{l}\text { Dissolved oxygen } \\
\left(\mathrm{mg} \mathrm{L}^{-1}\right)\end{array}$} & $07: 00$ & 328 & $7.89 \pm 0.09 \mathrm{aB}$ & $7.41 \pm 0.09 \mathrm{bB}$ & $7.46 \pm 0.09 \mathrm{bB}$ & $5.49 \pm 0.11 \mathrm{aB}$ & $5.81 \pm 0.11 \mathrm{aB}$ & $5.71 \pm 0.11 \mathrm{aB}$ \\
\hline & $17: 00$ & 328 & $11.85 \pm 0.10 \mathrm{aA}$ & $11.74 \pm 0.10 \mathrm{aA}$ & $11.16 \pm 0.10 \mathrm{bA}$ & $10.69 \pm 0.12 \mathrm{bA}$ & $11.47 \pm 0.12 \mathrm{aA}$ & $11.23 \pm 0.12 \mathrm{aA}$ \\
\hline $\mathrm{pH}$ & $17: 00$ & 44 & $7.55 \pm 0.02 \mathrm{a}$ & $7.54 \pm 0.02 \mathrm{a}$ & $7.46 \pm 0.02 \mathrm{~b}$ & $7.55 \pm 0.02 \mathrm{a}$ & $7.34 \pm 0.02 \mathrm{a}$ & $7.37 \pm 0.02 \mathrm{a}$ \\
\hline Salinity $\left(\mathrm{g} \mathrm{L}^{-1}\right)$ & $17: 00$ & 44 & $2.68 \pm 0.07 \mathrm{a}$ & $2.76 \pm 0.07 \mathrm{a}$ & $2.72 \pm 0.07 \mathrm{a}$ & $2.68 \pm 0.07 \mathrm{a}$ & $2.86 \pm 0.07 \mathrm{a}$ & $2.83 \pm 0.07 \mathrm{a}$ \\
\hline
\end{tabular}

${ }^{(1)}$ Means followed by equal letters, lowercase in the lines and uppercase in the columns, do not differ, by Tukey's test, at $5 \%$ probability. ${ }^{(2)}(10 \mathrm{~S}: 0 \mathrm{~T})$, shrimp monoculture with 10 shrimp per $\mathrm{m}^{2}$; (10S:0.5T), 10 shrimp per $\mathrm{m}^{2}$ and 0.5 tilapia per $\mathrm{m}^{2}$; (10S:1T), 10 shrimp per $\mathrm{m}^{2}$ and 1 tilapia per $\mathrm{m}^{2}$; (2T:0S), tilapia monoculture with 2 tilapia per $\mathrm{m}^{2} ;(2 \mathrm{~T}: 2.5 \mathrm{~S}), 2$ tilapia per $\mathrm{m}^{2}$ and 2.5 shrimp per $\mathrm{m}^{2} ;(2 \mathrm{~T}: 5 \mathrm{~S}), 2$ tilapia per $\mathrm{m}^{2}$ and 5 shrimp per $\mathrm{m}^{2}$. 
treatments with 4,8 and 12 shrimp per $\mathrm{m}^{2}$, respectively, with 2 tilapias per $\mathrm{m}^{2}$ in a 120-day culture with feed based on tilapia requirements only. Shrimp final mean weights were higher in that study, but tanks were aerated and the culture period was longer than the one of the present study.

In the (2T:2.5S) and (2T:5.0S) treatments, in which feed was provided based on tilapia requirements only, an excellent polyculture performance was observed. Feeding tilapias instead of shrimp has many advantages. Tilapia feed is cheaper and, because it is extruded and floats in the water column, tilapias can eat fast without competing with shrimp, which are grazing at the bottom of the pond. Shrimp eat almost everything they find in the environment, especially algae, detritus and other small organisms (Kent et al., 2011; Viau et al., 2012). By this strategy, shrimp feed on detritus settled from above, on bacterial film and also on uneaten feed particles which sink to the bottom. Tilapia fecal matter may also contribute to support shrimp growth (Yi et al., 2004).

When shrimp were introduced at 2.5 per $\mathrm{m}^{2}$ density, tilapia performance was not affected, which led to a high survival (98.75\%) with $499.16 \mathrm{~g} \mathrm{~m}^{-2}$ productivity, and a mean final weight of $260.62 \mathrm{~g}$ similar to that found in monoculture. As shrimp density increased to 5 shrimp per $\mathrm{m}^{2}$, tilapia yield $\left(455.79 \mathrm{~g} \mathrm{~m}^{-2}\right)$ and shrimp survival $(70.08 \%)$ significantly decreased. Tilapia survival (84 to $85 \%$ ) in the present experiment was: similar to the one reported by Bessa Junior et al. (2012) on a shrimp-tilapia (L. vannamei - O. niloticus) polyculture system (73 to $86 \%$ ); similar to Souza et al. (2009) study on a prawn-tilapia (Macrobrachium amazonicum - O. niloticus) polyculture system (85 to $88 \%$ ); and higher than the study reported by Uddin et al. (2009) on a prawn-tilapia (Macrobrachium rosenbergii - O. niloticus) polyculture (54 to 76\%).

García-Pérez et al. (2000) also reported no significant differences in prawn performance between monoculture ( 7 prawns per $\mathrm{m}^{2}$ ) and polyculture ( 7 prawns per $\mathrm{m}^{2}$, with 1 tilapia per $\mathrm{m}^{2}$ ) treatments in nonaerated earth ponds. Working with earth ponds without aeration, Santos \& Valenti (2002) also observed no significant differences among prawn (M. rosenbergii) reared in both monoculture and polyculture at three different densities (2, 4 and 6 prawns per $\left.\mathrm{m}^{2}\right)$, with tilapia (O. niloticus) at 1 fish per $\mathrm{m}^{2}$ density.
Because no significant differences were observed in yield, survival and FCR between tilapia monoculture (2T:0S) and tilapia-shrimp polyculture (2T:2.5S), shrimp introduction up to 2.5 shrimp per $\mathrm{m}^{2}$ density does not interfere on tilapia performance. García-Pérez et al. (2000) observed mean values of 294.2 and $276.9 \mathrm{~g} \mathrm{~m}^{-2}$ for tilapia monoculure and tilapia polyculture with $M$. rosenbergii, respectively.

Santos \& Valenti (2002) also reported that prawn (M. rosenbergii) addition to tilapia culture did not significantly affect tilapia yield varying from $344.5 \pm 31.5 \mathrm{~g} \mathrm{~m}^{-2}$, for tilapia monoculture, to $367.1 \pm 93.8$ and $385.7 \pm 37.2 \mathrm{~g} \mathrm{~m}^{-2}$ for polyculture. Even with a reduction on tilapia yield, when shrimp was introduced at a density of 5 shrimp per $\mathrm{m}^{2}$, it was possible to reach a shrimp yield of $30.55 \mathrm{~g} \mathrm{~m}^{-2}$ without any additional feed.

It is important to emphasize that, in the present experiment, no aeration or water exchange was provided to the tanks, in order to simulate a situation for small farmers. It is possible that with tilapia density reduced to 1 fish per $\mathrm{m}^{2}$, as by Santos \& Valenti (2002) and García-Pérez et al. (2000) experiments, a density of 5 shrimp per $\mathrm{m}^{2}$, would not affect shrimp performance in nonaerated tanks. In aerated tanks, Candido et al. (2005) reported a shrimp survival higher than $83 \%$, in a shrimp-tilapia polyculture.

Tilapia FCR was not affected in polyculture, even at 5 shrimp per $\mathrm{m}^{2}$ density. Yuan et al. (2010) also pointed out that there were no significant differences in FCR, in a tilapia-shrimp polyculture at low or high-tilapia density. Bessa Junior et al. (2012) also did not observe significant differences in FCR for densities of 2 tilapia per $\mathrm{m}^{2}$ and shrimp at $3,6,9,12$ shrimp per $\mathrm{m}^{2}$, with increased shrimp stoking density. The FCR was not affected in a tilapia-prawn polyculture, until the addition of 6 prawns per $\mathrm{m}^{2}$ with 1 tilapia per $\mathrm{m}^{2}$ (Santos \& Valenti, 2002). When feed is provided for tilapia in a polyculture system, competition for food is apparently negligible.

\section{Conclusions}

1. Tilapia-shrimp and shrimp-tilapia polyculture systems exert different influence on dissolved oxygen concentration.

2. Tilapia density increase in shrimp-tilapia polyculture system causes a decreased final weight,

Pesq. agropec. bras., Brasília, v.48, n.8, p.1088-1095, ago. 2013 DOI: 10.1590/S0100-204X2013000800039 
survival and yield, and an increased feed conversion rate (FCR) of shrimp; however, a shrimp density increase (2.5 shrimp per $\left.\mathrm{m}^{2}\right)$ in tilapia-shrimp polyculture system does not significantly affect the final weight, survival, yield and tilapia's FCR.

3. Feeding strategies based on the biomass of shrimp, in a polyculture system, decreases performance (final weight, survival, yield and FCR) of both species, in comparison with monoculture.

4. The combination of 2 tilapias and 2.5 or 5 shrimp per $\mathrm{m}^{2}$, with feed based on fish requirements, results in a more efficient polyculture system, with an increase of up to $57 \%$, in comparison to monoculture.

\section{Acknowledgments}

To Financiadora de Estudos e Projetos (Finep), for providing financial support for building aquaculture facilities; to Gabriela Cemirames, Hudson do Vale and Ana Valeria, for field and laboratory assistance.

\section{References}

BESSA JUNIOR, A.P.; AZEVEDO, C.M. da S.B.; PONTES, F.S.T.; HENRY-SILVA, G.G. Polyculture of Nile tilapia and shrimp at different stocking densities. Revista Brasileira de Zootecnia, v.41, p.1561-1569, 2012. DOI: 10.1590/S1516-35982012000700002.

CANDIDO, A.S.; MELO JUNIOR, A.P. de; COSTA, O.R.; COSTA, H.J.M. dos S.; IGARASHI, M.A. Efeito de diferentes densidades na conversão alimentar da tilápia Oreochromis niloticus com o camarão marinho Litopenaeus vannamei em sistema de policultivo. Revista Ciência Agronômica, v.36, p.279-284, 2005.

CLIFFORD, H.C. Marine shrimp pond management: a review. In: WYBAN, J. (Ed.). Proceedings of the special session on shrimp farming. Baton Rouge: World Aquaculture Society, 1992. p.110-137.

EL-SHERIF, M.S.; ALI MERVAT, A.M. Effect of rearing systems (mono- and poly-culture) on the performance of freshwater prawn (M. rosenbergii) juveniles. Journal of Fisheries and Aquatic Science, v.4, p.117-128, 2009. DOI: 10.3923/jfas.2009.117.128.

GARCÍA-PÉREZ, A.; ALSTON, D.E.; CORTÉS-MALDONADO, R. Growth, survival, yield, and size distributions of freshwater prawn Macrobrachium rosenbergii and tilapia Oreochromis niloticus in polyculture and monoculture systems in Puerto Rico. Journal of the World Aquaculture Society, v.31, p.446-451, 2000. DOI: 10.1111/j.1749-7345.2000.tb00894.x.

KENT, M.; BROWDY, C.L.; LEFLER, J.W. Consumption and digestion of suspended microbes by juvenile Pacific white shrimp Litopenaeus vannamei. Aquaculture, v.319, p.363-368, 2011. DOI: 10.1016/j.aquaculture.2011.06.048.

KUBITZA, F. Tilápia: tecnologia e planejamento na produção comercial. Jundiaí: Aqua Imagem, 2000. 289p.
LITTELL, R.C.; FREUND, R.J.; SPECTOR, P.C. SAS system for linear models. Cary: SAS Institute, 1991. 329p.

LUTZ, C.G. Polyculture: principles, practices, problems and promise. Aquaculture Magazine, v.29, p.34-39, 2003.

MARTÍNEZ-PORCHAS, M.; MARTÍNEZ-CÓRDOVA, L.R.; PORCHAS-CORNEJO, M.A.; LÓPEZ-ELÍAS, J.A. Shrimp polyculture: a potentially profitable, sustainable, but uncommon aquacultural practice. Reviews in Aquaculture, v.2, p.73-85, 2010. DOI: 10.1111/j.1753-5131.2010.01023.x.

MILSTEIN, A. Do management procedures affect the ecology of warm water polyculture ponds? World Aquaculture, v.28, p.12-19, 1997.

MUANGKEOW, B.; IKEJIMA, K; POWTONGSOOK, S; YI, Y. Effects of white shrimp, Litopenaeus vannamei (Boone), and Nile tilapia, Oreochromis niloticus L., stocking density on growth, nutrient conversion rate and economic return in integrated closed recirculation system. Aquaculture, v.269, p.363-376, 2007. DOI: 10.1016/j.aquaculture.2007.04.002.

NUNES, A.J.P.; MADRID, R.M.; ANDRADE, T.P. Carcinicultura marinha no Brasil: passado, presente e futuro. Panorama da Aqüicultura, v.21, p.26-33, 2011.

SANTOS, M.J.M. dos; VALENTI, W.C. Production of Nile tilapia Oreochromis niloticus and freshwater prawn Macrobrachium rosenbergii stocked at different densities in polyculture systems in Brazil. Journal of the World Aquaculture Society, v.33, p.369-376, 2002. DOI: 10.1111/j.1749-7345.2002.tb00513.x.

SHAHIN, J.; MONDAL, M.N.; WAHAB, M.A.; KUNDA, M. Effects of addition of tilapia in carp-prawn-mola polyculture system. Journal of the Bangladesh Agricultural University, v.9, p.147-157, 2011. DOI: 10.3329/jbau.v9i1.8757.

SOUZA, B.E. de; STRINGUETA, L.L.; BORDIGNON, A.C.; BOHNENBERGER, L.; BOSCOLO, W.R.; FEIDEN, A. Policultivo do camarão de água doce Macrobrachium amazonicum (Heller, 1862) com a tilápia do Nilo (Oreochromis niloticus) alimentadas com rações peletizada e farelada. Semina: Ciências Agrárias, v.30, p.225-232, 2009.

TENDENCIA, E.A.; BOSMA, R.H.; VERRETH, J.A.J. White spot syndrome virus (WSSV) risk factors associated with shrimp farming practices in polyculture and monoculture farms in the Philippines. Aquaculture, v.311, p.87-93, 2011. DOI: 10.1016/j. aquaculture.2010.11.039.

TENDENCIA, E.A.; FERMIN, A.C.; PENÃ M.R.; CHORESCA JUNIOR, C.H. Effect of Epinephelus coioides, Chanos chanos, and GIFT tilapia in polyculture with Penaeus monodon on the growth of the luminous bacteria Vibrio harveyi. Aquaculture, v.253, p.48-56, 2006. DOI: 10.1016/j.aquaculture.2005.06.028.

UDDIN, M.S.; AZIM, M.E.; WAHAB, M.A.; VERDEGEM, M.C.J. Effects of substrate addition and supplemental feeding on plankton composition and production in tilapia (Oreochromis niloticus) and freshwater prawn (Macrobrachium rosenbergii) polyculture. Aquaculture, v.297, p.99-105, 2009. DOI: 10.1016/j. aquaculture.2009.09.016.

UDDIN, M.S.; RAHMAN, S.M.S.; AZIM, M.E.; WAHAB, M.A.; VERDEGEM, M.C.J.; VENETH, J.A.J. Effects of stocking 
density on production and economics of Nile tilapia (Oreochromis niloticus) and freshwater prawn (Macrobrachium rosenbergii) polyculture in periphyton-based systems. Aquaculture Research, v.38, p.1759-1769, 2007. DOI: 10.1111/j.1365-2109.2007.01837 .x.

VAN WYK, P.; SCARPA, J. Water quality requirements and management. In: VAN WYK, P.; DAVIS-HODGKINS, M.; LARAMORE, R.; MAIN, K.L.; MOUNTAIN, J.; SCARPA, J. (Ed.). Farming marine shrimp in recirculating freshwater systems. Fort Pierce: Harbor Branch Oceanographic Institution, 1999. p.141-162.

VIAU, V.E.; SOUZA, D.M. de; M. RODRÍGUEZ, E.; WASIELESKY JUNIOR, W.; ABREU, P.C.; BALLESTER, E.L.C. Biofilm feeding by postlarvae of the pink shrimp Farfantepenaeus brasiliensis (Decapoda, Penaeidae). Aquaculture Research, p.1-12, 2012. DOI: 10.1111/j.1365-2109.2011.03087.x.
YI, Y.; FITZSIMMONS, K. Tilapia-shrimp polyculture in Thailand. In: INTERNATIONAL SYMPOSIUM ON TILAPIA IN AQUACULTURE, 6., 2004, Manila. New dimensions in farmed tilapia: proceedings. Manila: Bureau of Fisheries and Aquatic Resources, 2004. p.777-790.

YI, Y.; SAELEE, W.; NADITROM, P.; FITZSIMMONS, K. Stocking densities for tilapia-shrimp polyculture in Thailand. In: HARRIS, R.; COURTER, I.; EGNA, H. (Ed.). Aquaculture Collaborative Research Support Program. Corvallis: Oregon State University, 2004. p.105-113. (Twenty-first annual technical report - aquaculture CRSP).

YUAN, D.; YI, Y.; YAKUPITIYAGE, A.; FITZIMMONS, K.; DIANA, J.S. Effects of addition of red tilapia (Oreochromis spp.) at different densities and sizes on production, water quality and nutrient recovery of intensive culture of white shrimp (Litopenaeus vannamei) in cement tanks. Aquaculture, v.298, p.226-238, 2010. DOI: 10.1016/j.aquaculture.2009.11.011.

$\overline{\text { Received on May 17, } 2012 \text { and accepted on March 28, } 2013}$ 